Vol.3 No.2 Hal. 90 - 97

September 2020
BEST JOURNAI

(Biology Education,science \& Technolog̉y)

Fakultas Keguruan dan IImu Pendidikan
ISSN (Print) : $2614-8064$

ISSN (Online): $2654-4652$

\title{
Profil Pedagogical Content Knowledge (PCK) Guru Dalam Pembelajaran Biologi SMA Negeri 11 Medan Tembung T.P 2019/2020
}

\author{
Aisyah Rahma Nasution (1), Halim Simatupang ${ }^{(2)}$, Daryanti ${ }^{(3)}$, Alfrida Siregar ${ }^{(4)}$, Rohani \\ Regina Sagala $^{(5)}$, Supraba Ika Sari ${ }^{(6)}$, Mery K Sidabuke ${ }^{(7)}$ \\ Pendidikan Biologi Universitas Negeri Medan \\ Guru Biologi SMA Negeri 11 Medan
}

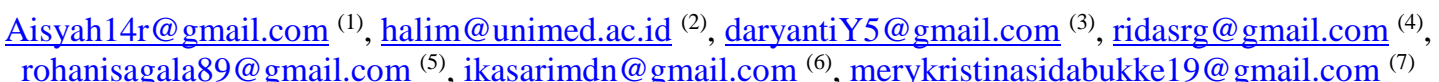

\begin{abstract}
ABSTRAK
Penelitian ini bertujuan untuk mengetahui Profil Pedagogical Content Knowledge (PCK) Guru dalam pembelajaran biologi di SMA Negeri 11 Medan Tembung Kota Medan T.P 2019/2020. Penelitian dilaksanakan pada tanggal 27 Januari 2020 hingga 25 Februari 2020. Sampel penelitian adalah seluruh Guru Biologi SMA Negeri 11 Medan Tembung. Instrument penelitian dengan triangulasi teknik yaitu memberikan dua jenis instrument berupa soal tes dan wawancara kepada satu sumber data serta peneliti sendiri sebagai instrument utama penelitian. Teknik pengambilan sampel dengan Total Sampling. Jenis penelitian ini adalah deskriptif Kualitatif. Hasil penelitian menunjukkan Profil PCK berdasarkan Komponen-komponen yang dimiliki PCK. Hasil penelitian menunjukkan hasil yang diperoleh pada Komponen Pengetahuan Materi Pembelajaran Sangat baik, Komponen pengetahuan Peserta Didik dan Karakteristiknya Cukup Baik, Komponen Pengetahuan Pedagogik Umum Sangat baik, Komponen Pengetahuan Komtent Pedagogik Kurang Baik, Komponen Pengetahuan Konteks Pembelajaran Cukup Baik, Komponen Pengetahuan Kurikulum baik, dan Komponen pengetahuan Strategi Mengejar Kurang Baik. Sehingga secara Keseluruhan Profil Pedagogical Content Knowledge yang dimiliki oleh Guru-Guru Biologi SMA Negeri 11 adalah Baik.
\end{abstract}

Kata Kunci : Profil, Pedagogical Content Knowledge (PCK), Pembelajaran Biologi

\begin{abstract}
The aim of this study was to determine the Pedagogical Content Knowledge (PCK) Profile of Teachers in Biology teaching in SMA Negeri 11 Medan Tembung, Medan in academic year of 2019/2020. The study was conducted on January 27, 2020 until February 25, 2020. The research sample was all biology teachers of SMA Negeri 11 Medan Tembung. The research instrument with technical triangulation is giving two instruments in the form of test questions and interviews to one data source and the researcher himself as the main research instrument. Total sampling was used as the sampling technique. The type of research was descriptive qualitative. The results showed that PCK profiles were based on the components of PCK. The results showed that the components of knowledge learning materials were very good, student knowledge components and characteristics were good enough, components of general pedagogical knowledge were very good, components of knowledge of pedagogical content were less good, knowledge components of learning contexts were good, knowledge components of curriculum were good, and the component of knowledge of teaching strategy was not good. In summary, overall Profiles of Pedagogical Content Knowledge possessed by Biology teachers of SMA Negeri 11 was good.
\end{abstract}

Keywords : Profil, Pedagogical Content Knowledge (PCK), Biology Learning 
Nasution Aisyah R, Simatupang H, Siregar A, Daryanti, Sagala Rohani R, Sari Supraba I, Sidabuke Mery K : Profil Pedagogical Content Knowledge (PCK) Guru Dalam Pembelajaran Biologi di SMA Negeri 11 Medan Tembung T.P 2019/2020

\section{PENDAHULUAN}

\section{Latar Belakang}

Kualitas pendidikan ditentukan bukan hanya oleh infrastuktur yang memadai tapi juga ditentukan oleh kualitas guru. Berdasarkan data yang diperoleh dari Uji Kompetensi Guru (UKG) pada tahun 2015 menyatakan bahwa nilai rata-rata hasil UKG nasional hanya mencapai $44,5 \%$ jauh dibawah nilai standar yang sudah di tetapkan secara nasional. Adapun berdasarkan data yang diperoleh dari Neraca Pendidikan Daerah (NPD) nilai pedagogic guru-guru yang ada di kota medan adalah 50,83 sedangkan nilai profesional guru adalah 58,66 yang mana rata-rata dari keseluruhan nilai adalah 56,31 (Syafitri, 2014).. Guru yang profesional dapat diwujudkan dengan beberapa cara salah satunya adalah dengan meningkatkan dan mengembangkan kualitas Pedagogical Content Knowledge (PCK) guru. Komponen penting yang dapat mengembangkan keprofesionalan pendidik (Guru) adalah PCK.

\section{Perumusan Masalah}

Berdasarkan hasil observasi dan wawancara yang dilakukan di SMA Negeri 11 di kecamatan Medan Tembung bahwa dari lima guru biologi yang ada di sekolah tersebut belum ada satupun yang lulus UKG Guru-guru di SMA Negeri 11 ini secara keseluruhan beranggapan bahwa UKG tidak dapat dijadikan patokan untuk menentukan profesionalitas seorang guru karena UKG yang terakhir dilakukan pada tahun 2015 dan dijadikan standarisasi rapot guru setiap tahunnya dan nilai UKG itu dipakai hingga sekarang yang mana setiap tahun standar kelulusannya juga semakin tinggi sehingga guru-guru yang awalnya telah lulus kemudian menjadi tidak lulus karena standarnya yang di naikkan sedangkan ujian yang dilakukan terakhirkalinya adalah di tahun 2015, karena hal ini guru-guru beranggapan bahwa UKG tidak layak dijadikan standarisasi tingkat profesionalitas atau kompetensi guru.

\section{Tujuan Penelitian}

Karena permasalahan yang banyak hadir di lapangan mengenai kegagalan dalam pembelajaran adalah hadir dari ketidak profesionalan guru dalam mengajar, maka penulis merasa penting untuk melakukan suatu penelitian mengenai PCK. Fokus kajian dalam penelitian ini ditujukan kepada guru biologi yang ada di kecamatan Medan Tembung untuk mengetahui bagaimana sebenarnya Profil Pedagogical Conten Knowledge yang dimiliki oleh guru-guru SMA N 11 yang ada di kecamatan Medan Tembung.

\section{Manfaat Penelitian}

Manfaat penelitian ini adalah memberi pengetahuan dan pemahaman bagi Pendidik harus memiliki PCK yang kuat agar dapat menjadi pendidik yang baik PCK merupakan pengetahuan tentang materi dan cara mengajarkannya atau campuran antara konten dan pedagogik yang membentuk suatu pengetahuan bagaimana suatu topik, masalah, atau isuisu diorganisasikan dan direpresentasikan yang disesuaikan dengan kemampuan pembelajar (Anwar $d k k, 2016)$.

\section{METODE PENELITIAN}

Penelitian ini dilaksanakan di SMA Negeri 11 yang beralamat di jalan pertiwi No. 93 Bantan, Kecamatan Medan Tembung Kota Medan Sumatera Utara. Populasi dalam penelitian ini adalah seluruh guru bidang studi Biologi di SMA Negeri 11dan telah sertifikasi pada Tahun Pembelajaran 2019/2020 yang berjumlah lima orang guru. Dalam penelitian ini jumlah sampel yang akan diteliti adalah lima orang guru biologi yang mengajar di SMAN 11. Jenis penelitian yang digunakan adalah penelitian deskriptif dengan menggunakan data 
Nasution Aisyah R, Simatupang H, Siregar A, Daryanti, Sagala Rohani R, Sari Supraba I, Sidabuke Mery K : Profil Pedagogical Content Knowledge (PCK) Guru Dalam Pembelajaran Biologi di SMA Negeri 11 Medan Tembung T.P 2019/2020

kualitatif. Instrumen penelitian adalah soal tes dan pedoman wawancara. Pada penelitian kualitatif, yang menjadi instrument utama adalah peneliti sendiri. Instrumen tes disusun dengan mengacu pada komponen-Komponen PCK Menurut Shulman (1987), Untuk standarisasi instrumen kemampuan PCK, peneliti menggunakan 2 validator ahli yaitu Ahli Materi Pedagogi, dan Ahli Konten materi. Instrument selanjutnya berupa Wawancara dilakukan pada sumber data, yaitu guru biologi SMA yang mengajar di SMA Negeri 11 Medan Tembung. Wawancara dilakukan guna menggali lebih dalam hasil tes dan menambah informasi terkait aspek-aspek PCK dan dijadikan sebagai bahan trianggulasi untuk mengecek kesesuaian data dan mencegah bias pada data. Teknik analisis data yang digunakan dalam penelitian ini adalah teknik analisis data interaktif mengikuti konsep yang dikemukakan oleh Miles dan Huberman Sugiyono (2017). Tahapan pertama dalam menganalisis data yakni Reduksi data, Mereduksi data berarti merangkum, memilih hal-hal yang pokok, memfokuskan pada hal-hal yang penting, mencari tema dan polanya. pada penelitian kali ini difokuskan pada teknik analisi data pada soal tes sebagai berikut: Untuk menganalisis data tes kemampuan PCK guru dilakukan dengan mencari persentase dan disajikan dalam bentuk deskriptif. Skor yang diberikan skor 1 untuk jawaban yang benar dan 0 untuk jawaban yang salah.

Keterangan:

$$
\text { Persentase }(\%)=\frac{n}{N} x 100 \%
$$

$\mathrm{P}=$ Persentase kemampuan PCK guru

$\mathrm{n}=$ Nilai yang diperoleh responden

$\mathrm{N}=$ Nilai yang diharapkan diperoleh responden

Hasil perhitungan persentase diinterpretasikan dalam tabel kemampuan PCK guru SMA Negeri di Kecamatan Medan Tembung yang Telah Sertifikasi berdasarkan rentang persentase menurut Sugiyono (2017).

Tabel Rentang Persentase Kemampuan PCK guru

\begin{tabular}{|l|l|}
\hline Rentang Persentase & Kemampuan PCK Guru \\
\hline $90 \%-100 \%$ & Sangat Baik \\
\hline $80 \%-89 \%$ & Baik \\
\hline $70 \%-79 \%$ & Cukup Baik \\
\hline $60 \%-69 \%$ & Kurang Baik \\
\hline$<60 \%$ & Tidak Baik \\
\hline
\end{tabular}

\section{HASIL DAN PEMBAHASAN}

Data profil PCK guru biologi SMA Negeri 11 Medan Tembung diperoleh dengan memberikan tes sebanyak 38 soal yang sudah di Validasi sebelumnya kepada dosen ahli yaitu ibu Dr. Widya Arwita S.Pd., M.Pd. dan telah dinyatakan layak untuk digunakan sebagai instrumen soal untuk mengukur tingkat pengetahuan PCK guru. Soal yang diberikan dikelompokkan menjadi tujuh komponen berdasarkan komponen-komponen PCK dan diberi penskoran. Terlebih dahulu akan dipaparkan hasil yang diperoleh secara keseluruhan dari soal yang diberikan lalu kemudian dideskripsikan berdasarkan komponen-komponen PCK. Secara keseluruhan rata-rata hasil dari setiap aspek komponen PCK yang diberikan pada guru biologi SMAN 11 dapat dirincikan seperti pada Tabel 2. 
Nasution Aisyah R, Simatupang H, Siregar A, Daryanti, Sagala Rohani R, Sari Supraba I, Sidabuke Mery K : Profil Pedagogical Content Knowledge (PCK) Guru Dalam Pembelajaran Biologi di SMA Negeri 11 Medan Tembung T.P 2019/2020

Tabel Hasil Tes PCK Guru Biologi SMA Negeri 11 Medan Tembung

\begin{tabular}{|c|c|c|c|c|c|c|c|c|c|}
\hline $\begin{array}{l}\text { Respond } \\
\text { en }\end{array}$ & & & $\begin{array}{l}\text { Kompon } \\
\text { en }\end{array}$ & PCK & & & & $\begin{array}{l}\text { Rata } \\
- \\
\text { Rata } \\
\end{array}$ & $\begin{array}{l}\text { Kriter } \\
\text { ia }\end{array}$ \\
\hline & A & B & $\mathrm{C}$ & D & $\mathrm{E}$ & $\mathrm{F}$ & $\mathrm{G}$ & & \\
\hline Guru 1 & 75 & 80 & 80 & 20 & 20 & 80 & 60 & $\begin{array}{l}59,2 \\
8\end{array}$ & $\begin{array}{l}\text { Kuran } \\
\text { g Baik }\end{array}$ \\
\hline Guru 2 & 88 & 80 & 100 & 40 & 40 & 60 & 40 & 64 & $\begin{array}{l}\text { Kuran } \\
\text { g Baik }\end{array}$ \\
\hline Guru 3 & 100 & 60 & 100 & 60 & 40 & 80 & 60 & $\begin{array}{l}71,4 \\
2\end{array}$ & $\begin{array}{l}\text { Cuku } \\
\text { p Baik }\end{array}$ \\
\hline Guru 4 & 88 & 80 & 100 & 60 & 60 & 40 & 40 & $\begin{array}{l}66,8 \\
5\end{array}$ & $\begin{array}{l}\text { Kuran } \\
\text { g Baik }\end{array}$ \\
\hline Guru 5 & 100 & 60 & 100 & 60 & 20 & 80 & 60 & 68,5 & $\begin{array}{l}\text { Kuran } \\
\text { g Baik }\end{array}$ \\
\hline Rata-rata & 90 & 72 & 96 & 48 & 36 & 68 & 52 & & \\
\hline Kriteria & $\begin{array}{l}\text { Sang } \\
\text { at } \\
\text { Baik } \\
\end{array}$ & $\begin{array}{l}\text { Cuku } \\
\mathrm{p} \\
\text { Baik }\end{array}$ & $\begin{array}{l}\text { Sangat } \\
\text { Baik }\end{array}$ & $\begin{array}{l}\text { Tida } \\
\mathrm{k} \\
\text { Baik }\end{array}$ & $\begin{array}{l}\text { Kuran } \\
\text { g } \\
\text { Baik } \\
\end{array}$ & $\begin{array}{l}\text { Kuran } \\
\text { g } \\
\text { Baik } \\
\end{array}$ & $\begin{array}{l}\text { Tida } \\
\mathrm{k} \\
\text { Baik } \\
\end{array}$ & & \\
\hline
\end{tabular}

Keterangan: A: Pengetahuan Materi Pembelajaran, B: Pengetahuan peserta didik dan karakteristiknya, C: Pengetahuan Pedagogik Umum, D: Pengetahuan content pedagogik, E: Pengetahuan Konteks Pembelajaran, F: pengetahuan kurikulum, G: Pengetahuan Strategi mengajar.

Dari Tabel di atas menunjukkan bahwa pada komponen PCK Pertama yakni Komponen pengetahuan materi pembelajaran ke lima guru mampu menjawab soal dengan baik, secara keseluruhan diperoleh rata-rata hasil ke lima guru pada komponen pengetahuan Materi pembelajaran sebesar $90 \%$ dengan kriteria sangat baik. Komponen PCK kedua yaitu Pengetahuan peserta didik dan Karakteristiknya dapat dilihat secara keseluruhan rata-rata persentase hasil yang diperoleh guru adalah sebesar $72 \%$ dengan kriteria cukup baik. Komponen PCK ketiga pada komponen pengetahuan pedagogik umum ini, guru memperoleh persentase hasil 96\%, dengan kriteria sangat baik. Komponen PCK keempat secara keseluruhan rata-rata persentase hasil yang diperoleh guru pada komponen pegetahuan content pedagogik adalah $48 \%$, dengan kriteria tergolong tidak baik. Komponen PCK kelima yaitu pengetahuan konteks pembelajaran, rata-rata persentase hasil yang diperoleh guru pada komponen ini adalah 36\%, dengan kriteria tergolong tidak baik. Komponen PCK keenam yaitu mengenai pengetahuan kurikulum rata-rata hasil yang diperoleh pada komponen ini adalah 68\%. dengan kriteria tergolong kurang baik. Komponen PCK ketujuh sekaligus komponen terakhir PCK, yaitu pengetahuan strategi mengajar hasil rata-rata yang diperoleh pada komponen ini adalah 52\%, dengan kriteria tergolong sangat baik.

\section{PEMBAHASAN}

\section{Komponen Materi pembelajaran}

Profil PCK guru di SMA Negeri 11 Medan Tembung Pada Komponen materi pembelajaran ditemukan kriteria sangat baik, hal ini berdasarkan hasil tes yang diperoleh dan juga berdasarkan hasil wawancara. Diketahui bahwa guru-guru di SMA Negeri 11 telah mengajar lebih dari 10 tahun dan hal ini menjadikan guru-guru biologi di SMA Negeri 11 sudah sangat menguasai materi yang mereka ajarkan karena telah mengajarkan materi tersebut dalam 
Nasution Aisyah R, Simatupang H, Siregar A, Daryanti, Sagala Rohani R, Sari Supraba I, Sidabuke Mery K : Profil Pedagogical Content Knowledge (PCK) Guru Dalam Pembelajaran Biologi di SMA Negeri 11 Medan Tembung T.P 2019/2020

kurun waktu yang lama hal ini sejalan dengan yang dikemukakan oleh Yenni (2014) bahwa seharusnya seorang guru memiliki pengetahuan khusus yang diperoleh dari proses mengajar yang telah dilakukan bertahun-tahun dan dari pengembangan profesi. Penelitian yang dilakukan oleh (Subanji, 2015) bahwa pengalaman guru dalam mengajar akan dapat dijadikan sebagai upaya pengembangan kompetensi yang dimiliki guru dan dengan rentang waktu yang telah dilaluinya guru akan mampu menemukan sendiri cara mengajar (teori dan Praktik) dalam artian teori yang akan diajarkan maupun praktik dalam mengajar. Guru-guru biologi yang mengajar di SMA Negeri 11 adalah guru-guru yang juga memiliki latar belakang pendidikan yang sesuai dengan bidang ajar yang diampuhnya, empat orang guru biologi di SMA Negeri 11 ini adalah alumni Universitas Negeri Medan (Unimed) dengan jurusan pendidikan biologi dengan angkatan yang berbeda-beda dan satu orang lainnya berasal dari Universitas dengan jurusan pendidikan biologi juga, sejalan dengan yang dikemukakan oleh Hamzah (2008) bahwa salah satu hal yang mempengaruhi profesionalitas seseorang adalah latar belakang pendidikan yang ditempuh.

\section{Komponen Pengetahuan Peserta didik dan Karakteristiknya}

Profil PCK guru SMA Negeri 11 Medan Tembung pada komponen pengetahuan peserta didik dan karakteristiknya ditemukan dengan kriteria cukup baik, hal ini sejalan dengan hasil wawancara yang dilakukan dimana guru-guru di SMA Negeri 11 cukup baik. Guru yang memahami karakteristik peserta didiknya adalah guru yang mampu membantu peserta didik dalam upaya membantu proses pembelajaran yang meliputi aspek fisik, intelektual, sosial dan emosional (Mukhtar, 2001) bahwa guru seyogyanya mengenali setiap siswa dikelasnya secara individu dengan segala keunikannya, melalui pengamatan yang cermat, sehingga bisa memahami kekurangan dan kelebihan masing-masing. Dalam hal membantu mengembangkan potensi peserta didik guru biologi di SMA Negeri 11 cenderung tidak memberikan perhatian lebih kepada siswanya dan menyerahkan hal tersebut sepenuhnya kepada kegiatan ekstrakurikuler dan usaha mandiri siswa sehingga dalam hal ini guru tidak mengambil peran sehingga menjadi suatu yang berbeda dengan peran guru yang saharusnya dimana menurut jurnal (Yohafrinal et al., 2015) seorang guru yang professional, semestinya seorang guru mengetahui kelebihan dan kelemahan setiap peserta didik sehingga dengan pengetahuan tersebut akan tercipta kegiatan pembelajaran yang lebih bermakna. Pemahaman guru terhadap peserta didiknya inilah yang sejatinya menjadi pembeda antara seotang guru yang mentransfer ilmu pengetahuan kepada siswanya dengan seorang tentor yang sedang menjelaskan materi kepada siswa. hal yang menyebabkan guru tidak mampu untuk mengoptimalkan peranannya untuk dapat mengetahui peserta didik dengan karakteristiknya disebabkan oleh keterbatasa-keterbatasan yang dimiliki guru untuk melaksanakannya, karena guru tidak memiliki cukup waktu, jumlah peserta didik yang yang cukup besar dalam satu ruangan kelas dan banyaknya jumlah kelas yang harus dimasuki oleh guru setiap harinya menjadi penyebab utama tidak optimalnya peranan guru terhadap peserta didiknya khususnya dalam komponen pengetahuan peserta didik dan karakteristiknya hal ini sejalan dengan apa yang dikemukakan (Nurhamidah, 2018) bahwa permasalahan yang dihadapi guru tentang penguasaan guru terhadap karakteristik siswa adalah ketidakmampuan guru dalam menguasai karakteristik aspek moral-emosional, sosio-kultural, aspek fisik, intelektual, moral dan karakter belajar yang dimiliki oleh peserta didik.

\section{Komponen Pengetahuan Pedagogik Umum}

Profil PCK guru di SMA Negeri 11 Medan Tembung pada komponen Pengetahuan Pedagogik umum ditemukan dengan kriteria sangat baik, hal ini sejalan dengan hasil wawancara yang dilakukan dimana guru-guru memiliki metode yang unik untuk memastikan 
Nasution Aisyah R, Simatupang H, Siregar A, Daryanti, Sagala Rohani R, Sari Supraba I, Sidabuke Mery K : Profil Pedagogical Content Knowledge (PCK) Guru Dalam Pembelajaran Biologi di SMA Negeri 11 Medan Tembung T.P 2019/2020

setiap anak siap dalam mengikuti proses pembelajaran dan memiliki perbedaan pada satu guru dan guru yang lainnya, untuk memberikan gambaran terkait proses pembelajaran berdasarkan wawancara diketahui bahwa: "Ibu suka melakukan prraktikum dalam proses pembelajaran untuk materi yang memang memungkinkan untuk melakukan praktikum, tapi kalau misalnya tidak ada bahan di laboratorium atau kendala takut waktu tidak cukup paling ibu cuman menyuruh mereka membawa misalnya kalau kita belajar tentang tumbuhan paku ibu suruh mereka bawa bunga suplir atau yang lainnya sehingga bisa ditunjukkan pada mereka missal letak spora secara langsung dalam proses pembelajaran".Guru juga mengatakan bahwa dalam memberikan nilai untuk siswa guru tidak hanya melihat dari hasil belajar saat diujian saja tapi mengedepankan karakter yang dimiliki siswa dalam keseharian proses pembelajaran dan juga dari hasil ulangan harian yang dilakukan guru setiap bulannya. dalam tulisannya Margiyono (2011) memaparkan bahwa Evaluasi atas proses pembelajaran dilakukan oleh guru untuk melihat ketercapaian tujuan pembelajaran oleh siswa. Hamzah (2008) mengemukakan kompetensi profesional juga dipengaruhi oleh latar belakang pendidikan, pengalaman mengajar dan lamanya mengajar. Sejalan juga dengan yang dikemukakan oleh (Maryani, 2016) bahwa LPTK adalah lembaga yang bertanggung jawab mengemban tugas untuk menyiapkan guru profesional dan menuntut kemampuan akademik, pedagogik, sosial maupun profesional. Anwar (2016) mengungkapkan seyogianya guru harus terus mengembangkan proses mengajarnya di kelas dan jika usaha untuk terus mengembangkan proses belajar di dalam kelas telah berlangsung selama 10 tahun bahkan lebih maka akan terbentuk seorang pribadi guru dengan profesionalitas yang tinggi.

\section{Komponen Pengetahuan Konten pedagogic}

Profil PCK guru di SMA Negeri 11 Medan Tembung pada Komponen pengetahuan konten pedagogic ditemukan dengan kriteria Kurang baik. jika ditinjau berdasarkan hasil tes kemampuan PCK yang telah dilakukan, hasil yang diperoleh guru-guru biologi SMA Negeri 11 Medan tembung adalah termasuk dalam kriteria tidak baik. Berdasarkan hasil penelitian yang telah diperoleh guru memiliki hasil yang baik pada komponen pengetahuan materi dan memiliki hasil yang baik pada komponen pedagogik umum dan pada hal ini memiliki hasil yang rendah pada komponen pengetahuan konten pedagogik, hasil yang rendah yang diperoleh pada komponen ini menunjukkan guru tidak mampu dalam mengorganisasikan kedua aspek tersebut membentuk suatu aspek atau komponen yang baru sehingga guru menunjukkan hasil yang rendah, hal ini juga sejalan dengan hasil wawancara dimana guru mengaku salah satu cara yang dilakukan oleh guru untuk mengatasi siswa yang kurang bersemangat dalam belajar adalah dengan memberikan tuntutan tugas dengan ancaman berupa nilai yang rendah akan diberikan jika siswa tidak mau mengerjakan tugas yang diberikan. Guru beranggapan bahwa tidak semua anak atau peserta didik di tuntut untuk memahami materi yang diajarkan karena bisa jadi siswa tersebut memiliki keahlian pada bidang lain atau menyukai pelajaran lain. Fakta yang diperoleh dari hasil wawancara yang berasal dari kelima guru yang telah dilakukan menunjukkan bahwa dalam hal ini guru memang masih merasa kewalahan dalam menghadapi siswa padalah seharusnya guru perlu untuk memberikan perhatian lebih untuk kasus-kasus seperti ini dan dalam hal ini seharusnya guru penting untuk menjadi guru yang inovator sebagaimana yang dikemukakan oleh Mukhtar (2001).

\section{Komponen Pengetahuan Konteks Pembelajaran}

Profil PCK guru di SMA Negeri 11 pada komponen pengetahuan konteks pembelajaran ditemukan dengan kriteria cukup baik. Jika hanya dilihat pada hasil tes berdasarkan hasil tes pengetahuan PCK yang telah dilakukan guru-guru biologi di SMA negeri 11 Medan 
Nasution Aisyah R, Simatupang H, Siregar A, Daryanti, Sagala Rohani R, Sari Supraba I, Sidabuke Mery K : Profil Pedagogical Content Knowledge (PCK) Guru Dalam Pembelajaran Biologi di SMA Negeri 11 Medan Tembung T.P 2019/2020

Tembung memperoleh hasil dengan kriteria tidak baik, hal ini menunjukkan dari lima soal yang diberikan tentang pengetahuan konteks pembelajaran ini guru-guru di SMA Negeri 11 Medan Tembung haya mampu menjawab dengan benar satu atau dua soal saja dan selebihnya jawaban yang diberikan oleh guru salah. Untuk nenetapkan bahwa guru-guru biologi di SMA Negeri 11 memiliki profil yang tidak baik hanya dengan melihat dari hasil tes kemampuan PCK yang telah dijawab oleh guru dianggap kurang tepat hal ini juga sejalan dengan apa yang dikemukakan oleh Kriyantono (2006) yang mngungkapkan bahwa riset kualitatif bertujuan untuk menjelaskan fenomena dengan sedalam dalamnya melalui pengumpulan data dan data yang diperoleh membutuhkan data yang mendalam pula, oleh karena itu perlu adanya fakta lain atau data lain yang mendukung terhadap hasil ini sehingga diperoleh data yang mendalam. Wawancara yang dilakukan diketahui bahwa guru-guru biologi di SMA Negeri 11 aktif dalam melaksanakan pembelajaran di laboratorium untuk materi yang memungkinkan siswa untuk dibawa belajar di laboratorium dan jika tidak memungkinkan untuk belajar berdasarkan hasil wawancara diketahui pada beberapa jenis materi pembelajaran siswa diminta oleh guru untuk membawa beberapa jenis tumbuhan dan benda untuk dijadikan bahan dalam proses pembelajaran hal ini menunjukkan terjadinya proses pembelajaran secara kontekstual antara guru dengan siswa. Sanjaya (2005) mengungkapkan bahwa konteks pembelajaran menjadikan siswa terlibat secara penuh dalam menenukan materi yang dipelajari dan dapat menghubungkan materi tersebut dengan keseharian mereka sehingga menjadi ilmu yang dapat diterapkan oleh siswa dalam kehidupan mereka.

\section{KESIMPULAN}

Profil Pedagogical Content Knowledge ( PCK) yang dimiliki oleh guru-guru Biologi di SMA Negeri 11 jika diuraikan terdiri dari tujuh komponen PCK maka Profil PCK yang dimiliki guru adalah: 1) Komponen pengetahuan materi pembelajaran dengan profil sangat baik, 2) Komponen pengetahuan peserta didik dan karakteristiknya dengan profil cukup baik, 3) Komponen pengetahuan pedagogik umum dengan profil sangat baik, 4) Komponen pengetahuan konten pedagogik dengan profil kurang baik, 5) Pengetahuan konteks pembelajaran dengan profil cukup baik, 6) Komponen pengetahuan kurikulum dengan profil baik, 7) Pengetahuan Strategi mengajar dengan profil kurang baik. jadi secara keseluruhan dari tujuh komponen terdapat dua komponen dengan kriteria sangat baik, satu komponen dengan kriteria baik, dua komponen dengan criteria cukup baik dan terdapat dua komponen dengan kriteria kurang baik, sehingga merujuk kepada hasil secara keseluruhan penulis dapat menyimpulkan bahwa profil PCK guru-guru biologi SMA Negeri 11 Medan Tembung adalah baik.

\section{DAFTAR PUSTAKA}

Anwar, Y., Rustaman, N. Y., Widodo, A., \& Redjeki, S. (2016). Perkembangan Kemampuan Pedagogical Content Knowledge Calon Guru Biologi pada Pendekatan Konkuren. Jurnal Cakrawala Pendidikan, 3: 349-356.

Chairunnissa, Connie. (2017). Metode Penelitian Ilmiah Aplikasi Dalam Pendidikan dan Sosial. Jakarta: Mitra Wacana Media.

Hamzah. (2008). Profesi Kependidikan Problem Solusi, dan Reformasi Pendidikan di Indonesia. Jakarta: Bumi Aksara.

Kriyantono, Rachmat. (2006). Teknik Riset Komunikasi. Jakart: Prenada.

Margiyono, Mampouw. (2011). Deskripsi Pedagogical Content Knowledge Guru Pada Bahasan Tentang Bilangan Rasional. Pulikasi Seminar Nasional. 
Nasution Aisyah R, Simatupang H, Siregar A, Daryanti, Sagala Rohani R, Sari Supraba I, Sidabuke Mery K : Profil Pedagogical Content Knowledge (PCK) Guru Dalam Pembelajaran Biologi di SMA Negeri 11 Medan Tembung T.P 2019/2020

Maryani. (2016). Strategi LPTK Dalam Mengembangkan Kompotensi Pedagogik Calon Guru. Jurnal Pendidikan. 1(2), 98-106.

Maulipaksi, Desliana. (2016). 7 Provinsi Raih Nilai Terbaik Uji Kompetensi Guru 2015. [Online]. http://www.kemdikbud.go.id/main/blog/2016/01/7-provinsi-raih-nilaiterbaik-uji-kompetensi-guru-2015. Diakses 25 Februari 2016.

Mukhtar, dkk, (2001). Mengukur Prestasi Panduan Menjadi Guru Profesional. Jakarta: Misaka Galiza.

Nurhamidah. (2018). Problematika Kompetensi Pedagogi Guru Terhadap Karakteristik Peserta Didik. Jurnal Teori dan Praksis Pembelajaran. 3(1): 27-38

Palupi, R., Anita, S., Budiyono. (2014).Hubungan antara Motivasi Belajar dan Prestasi Siswa Terhadap Kinerja Guru dalam Mengelola Kegiatan Belajar dangan Hasil Belajar IPA siswa Kelas VIII di SMPN 1 Pasitan .Jurnal Tecnologi Pendidikan dan Pembelajaran.2(2): 2354-6441.

Sanjaya. (2005). Profesi Kependidikan Problem, Solusi, dan Reformasi Pendidikan di Indonesia. Jakarta: Alfabeta.

Shulman, L. S. (1987). Knowledge and Teaching: Foundations of the New Reform. Havard Educational Review. 57(1), 1-21.

Subanji. (2015). Peningkatan Pedagogical Content Knowledge Guru Matematika dan Praktiknya dalam Pembelajaran Melalui Model Pelatihan TEQIP. Jurnal Ilmu Pendidikan, 21(1).

Sugiyono. (2017). Metode Penelitian Kuantitatif, Kualitatif dan R\&D. Bandung: Alfabeta.

Syafitri. (2014). Efektivitas Pembelajaran Biologi Menggunakan Metode Role Playing Dalam Meningkatkan Hasil Belajar Dan Aktivitas Siswa Pada Sub Materi Sistem Pencernaanmanusia Di Kelas Xi Ipa Sma Negeri 8 Medan Tahun Pembelajaran 2013/2014.Medan: Unimed Press.

Winarni, Endang W. (2018). Teori dan Prakttik Penenlitian Kuantitatiif Kualitatif Penelitaian Tindakan Kelas (PTK) Research and Development (R\&D). Jakarta: Bumi Aksara.

Yenni, E., Firdaus, L. N., \& Yosua, H. (2014). Analisis keterampilan technological pedagogical content knowledge (TPCK) guru biologi SMA Negeri Kota Pekanbaru. Jurnal Biogenesis, 11(1), 67-72.

Yohafrinal, Damris, \& Risnita. (2015). Analysis Pedagogical Content Knowledge Mathematic of science's teachers SMA Negeri 11 Kota Jambi. Jurnal Edu-Sains, 4(2), $15-24$.

\begin{tabular}{|l|l|l|l|}
\hline Accepted Date & Revised Date & Decided Date & Accepted to Publish \\
\hline 14 Agustus 2020 & 15 Agustus 2020 & 18 Agustus 2020 & Ya \\
\hline
\end{tabular}

